\title{
THE CONSTRUCTION OF POLITICAL
}

\section{SUPERIORITY}

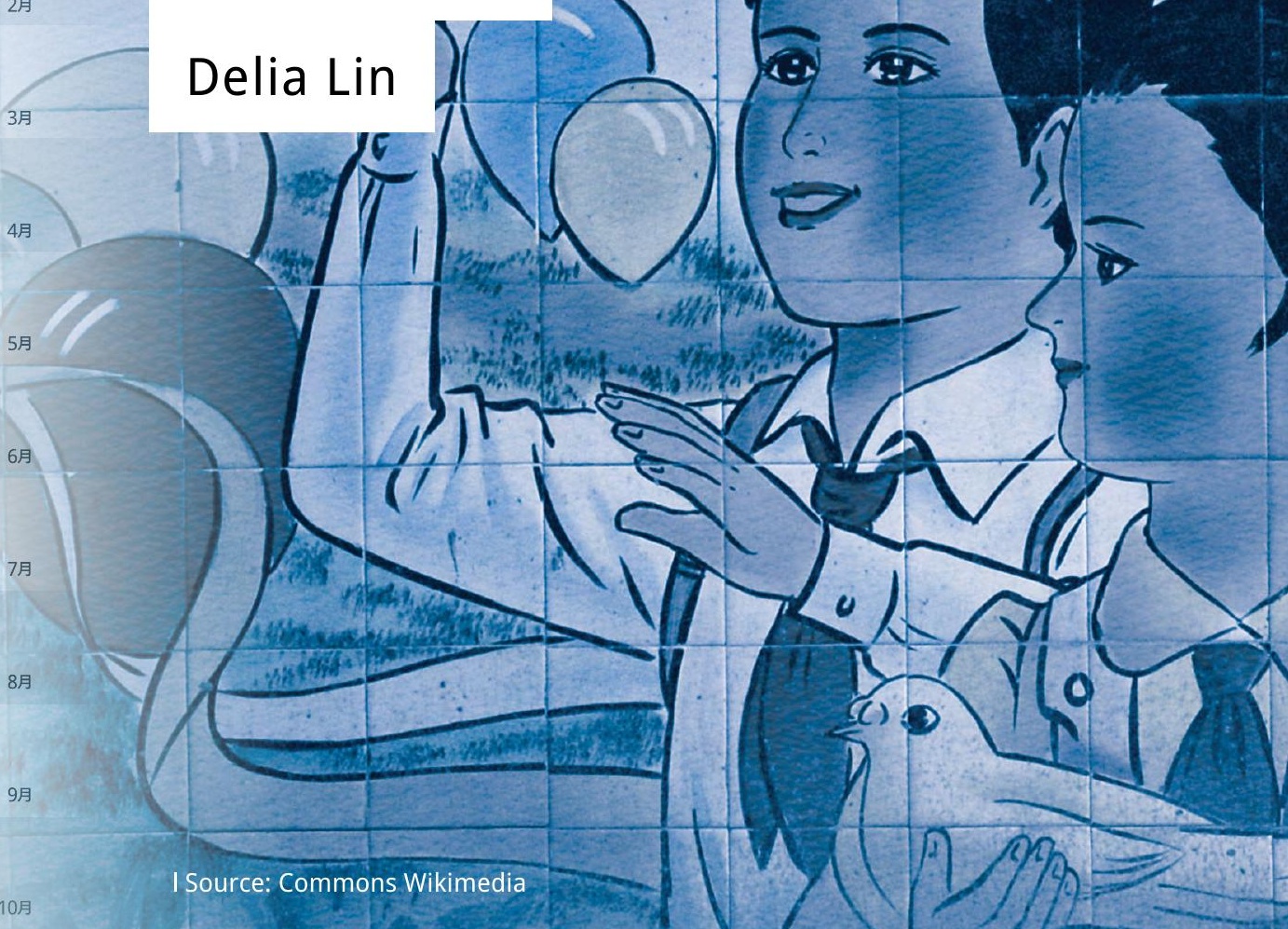




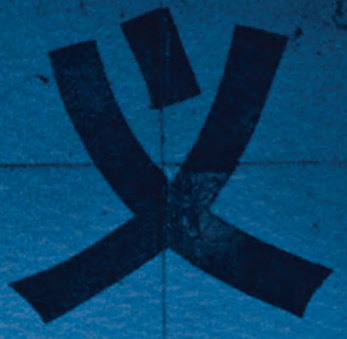

THE NOTION OF the 'superiority of the political system' 制度优越性 of the People's Republic of China (PRC) is at the heart of the construction of national 'confidence' 自信 in the Xi Jinping 习近平 era. Quoting President Xi Jinping’s speeches, Chinese Communist Party (CCP) theoreticians attribute China's success in containing the COVID-19 pandemic and Western countries' perceived failure to do so to both the 'political advantages' 政治优势 of CCP-led Socialism with Chinese Characteristics 中国 特色社会主义 and the futility of Western multi-party democracy. The depiction of the CCP's authoritarian rule as intrinsically and altruistically virtuous and of Western multi-party democracy as a source of indifference, conflict, social division, and even catastrophe is not entirely new. But the pandemic has provided the CCP with an unprecedented opportunity to assert the PRC's systemic superiority as an analytical tool in its ideological promotion and dissemination both at home and abroad.

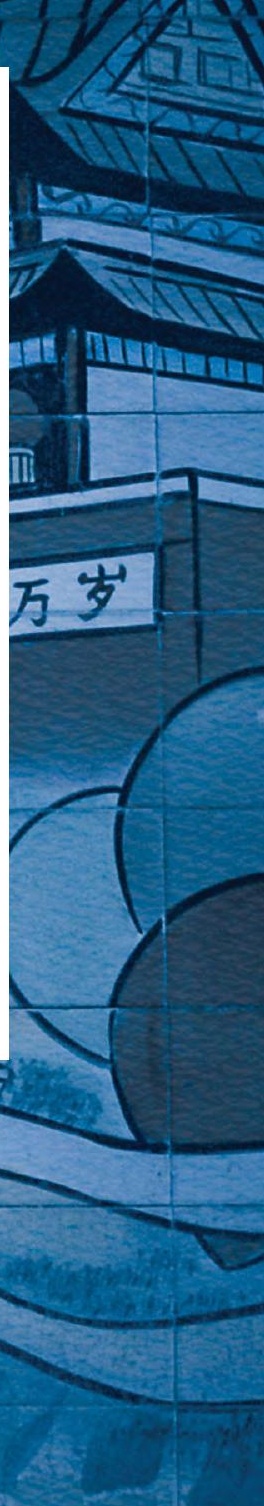




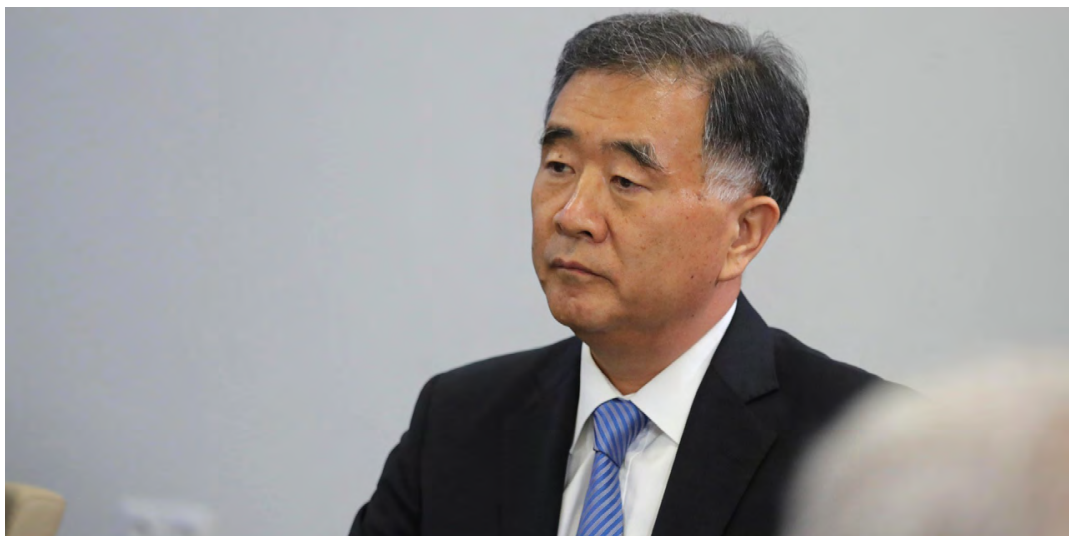

Vice Premier of the Chinese State Council Wang Yang

Source: President of Russia, Kremlin website

\section{Viewing the Pandemic Through the Lens of Political Superiority}

Party leaders and academics have long claimed the superiority of China's particular form of socialism over capitalism, attributing China's accomplishments to its unique political system and the leadership of the CCP, including the rapid economic development of the post-Mao Reform Era. ${ }^{1}$ Those outside observers who treat this as mere rhetoric are in danger of misunderstanding the advocates of economic reform as somehow automatically at odds with the socialist system. At the National People's Congress in 2013, newly appointed member of the CCP Politburo Wang Yang 汪洋, widely acclaimed in the West as an avid proponent of reform, told the delegates of his home province of Anhui that the West was anxious about the rise of China - not because of its growing economic, technological, and military strength, but because of the superiority of the Chinese political system over Western models. ${ }^{2}$

With China on its way to recovery from the pandemic while the US, the UK, and numerous European countries have struggled to get on top of the public health crisis, the CCP was quick to credit the Chinese experience 
of controlling the virus as indisputable proof of this superiority. The central government white paper on the pandemic, issued on 7 June, portrayed the process as a grand battle - a 'people's war' 人民战争 under Xi Jinping's 'personal command' 亲自指挥 — that showcased the strength and advantages of the CCP-led Chinese political system. ${ }^{3}$

Soon after the publication of the white paper, the Central Party School's bi-monthly political theory journal Qiushi 求是 published an article titled 'Battling against the pandemic highlights the superiority of the political system of Socialism with Chinese Characteristics'. The author was Qin Gang 秦刚, a research professor in the school's Centre for Xi Jinping Thought on Socialism with Chinese Characteristics for the New Era. ${ }^{4}$ It was soon widely republished in national, provincial and local print, and online media, including the People's Daily and Xinhuanet. The article places the Chinese political system and Western-style democracy side-by-side to make a comparative moral evaluation. It outlines five key 'institutional advantages' 制度优势 of the former over the latter: centralised, unified party leadership; the prioritisation of collective interests; adherence to 'the principal status of the people' 人民主体地位; powerful social mobilisation capabilities; and 'governing the country in accordance with the law' 依法治国. The article claims that, as it represents the 'people', the CCP has no self-interest: everything it does is to realise and maintain the common interests of the majority of the people while caring for different needs and concerns.

In contrast, political parties in the West, primarily represent interest groups. Fighting on their behalf, parties therefore attack and frustrate one another. Policy-making and legislation become acts of deal-making, which not only undermine the stability of policies and laws but also exacerbate social divisions. The article states that, during the pandemic, political parties in some Western countries focused on partisan bickering, shirking their broader responsibilities to society or spending too much time deliberating and consulting rather than making decisions - hence the catastrophic spread of the virus. By contrast, public ownership and 
democratic centralism 民主集中制 (in which the people's congresses at the national and local levels may go through an election process but are subject to central leadership) enabled the CCP to mobilise its members and society at large and 'concentrate its strength to accomplish big goals and difficult tasks' 集中力量办大事办难事. Qin Gang also accused some 'socalled "human rights defenders"' in the West - presumably those critical of the Chinese state's actions in Xinjiang and Hong Kong - of numb indifference to the lives of people in their own countries, including those damaged by the pandemic.

Similar to his comparative evaluation of political parties, Qin Gang offers a particular interpretation of the values and principles underpinning the Western capitalist system and the Chinese socialist system:

The socialist system emphasises the supremacy of the general interest. This is completely different from the capitalist system. The capitalist system is a social institution with individualism as its core principle, placing individual interests above national and collective interests. Individualism was originally a weapon used by the bourgeoisie to fight feudal tyranny. When the bourgeoisie ascended to the ruling class, individualism became national ideology and the basis for the capitalist institutional structure as well as the foundation of national and social life. Individualism always firmly places individuals at the centre of society and personal relationships. This ego-centric individualism not only leads to alienation between individuals but also generates selfishness. During the devastating outbreak of the pandemic, individualism causes the social members to care only about their own so-called 'rights' and 'freedom' and be unwilling to accept any restrictions on their behaviour. They lack the concept of the collective and the awareness of the overall situation and many Western countries have paid a high price for it. ${ }^{5}$ 
Following this criticism of the selfish tendencies of individualism, Qin Gang praises the Chinese socialist system's insistence on placing the interests of the nation, the people, and the collective above individual interests. He postulates that this not only fundamentally resolves conflicts of interest among individuals, but also helps motivate and mobilise the entire society. It is the ethical and ideological foundation of the governance mechanism described as 'the whole nation playing a single game’ 全国一盘棋. This explains why, according to the article, the majority of Chinese people had an 'awareness of the overall situation' 大局意识 and were thus able to restrain and even sacrifice themselves during the fight against the pandemic.

Numerous articles in print, online, and social media have repeated this crediting of China's achievements in pandemic control to the superiority of its political system, while blaming the deteriorating situation in the US and other Western countries on weak and flawed Western-style democracy with its poor moral foundations.

\section{From Justification to Confidence-Building}

The formulation of the Chinese phrase 'Socialism with Chinese Characteristics' has undergone three official revisions over two decades. When Deng Xiaoping 邓小平 initially coined the term during the opening ceremony of the Twelfth Party Congress in 1982, it was called 有中国特 色的社会主义 (literally, socialism that has Chinese features). ${ }^{6}$ Deng's use of 有, meaning 'has' or 'with', and the possessive particle 的 suggests he was calling for an adaptation of Maoist definitions of socialism to China's contemporary needs and characteristics. Indeed, Deng's speech emphasised that the CCP needed to integrate the 'universal truth of Marxism' with China's specific reality while borrowing useful ideas from foreign countries. ${ }^{7}$ It is unknown whether Deng was referring to the then powerful socialist Soviet Union or Western democracies, but either way 
the introduction of 'socialism with Chinese features' justified adhering to the ideology of socialism while introducing capitalist market mechanisms into the economy.

Ten years later, in 1992, Jiang Zemin's 江泽民 report to the Fourteenth Party Congress updated the term to 有中国特色社会主义 (literally, socialism having Chinese features). ${ }^{8}$ The possessive particle 的 was omitted, suggesting a fusion in which the Chinese version of socialism is seen as a unique political system rather than a part of, or variation on, the greater socialist family.

Only in 2002, with Jiang's report to the Sixteenth Party Congress, did the term evolve into its current form, 中国特色社会主义, in which the first character, 有, was also removed, further linguistically cementing the idea of a self-standing sinicised socialism. ${ }^{9}$ Fifteen years later, in 2017, during the Nineteenth Party Congress, Xi Jinping added 'the new era' 新时代 to the term to frame it as a pathway to achieving the grand China Dream of national rejuvenation. ${ }^{10}$ In October 2019, for the first time in the history of the CCP, a plenary session of the Central Committee was held especially to discuss the advantages of China's political system and governance, at the end of which it issued a 'decision paper'. ${ }^{11}$

During the Eighteenth Party Congress in 2012, then general secretary $\mathrm{Hu}$ Jintao 胡锦涛 had introduced the confidence doctrine for Socialism with Chinese Characteristics, calling for the Party to be confident in its chosen path 道路自信, guiding theories 理论自信, and political system 制度自信. ${ }^{12}$ In his speech celebrating the ninety-fifth anniversary of the founding of the CCP in 2014, Xi Jinping added cultural confidence 文化自信. ${ }^{13}$ The Four Confidences 四个自信 — in the path, theory, system, and culture of Socialism with Chinese Characteristics - were enshrined in the CCP Constitution following the Nineteenth Party Congress in 2017. ${ }^{14}$ Xi's addition of 'cultural confidence' added an element of cultural and traditional determinism to the 


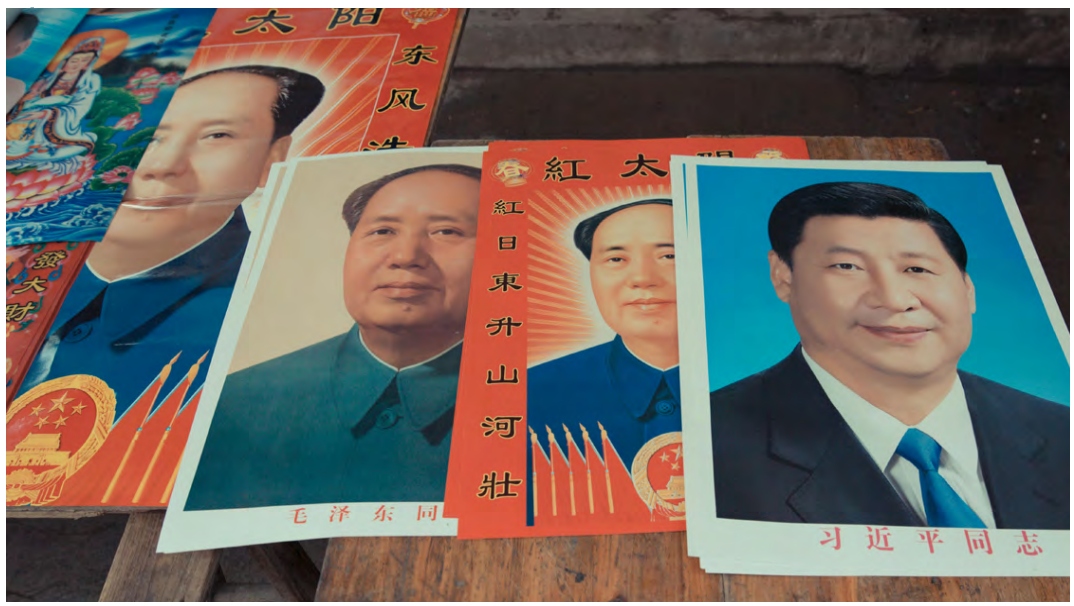

Xi's new era differs from Mao-style top-down condemnation of liberalism Source: Françoise Gaujour, Flickr

political system. As Xi remarked to former Greek prime minister Antonis Samaras: 'Your democracy is ancient Greek and Roman democracy. That is your tradition. We have our own tradition. ${ }^{15}$

In Xi's new era, rejection of a Western-style democratic political model is not exercised through a Mao-style top-down condemnation of liberalism. Rather, it is done through a party-endorsed reconstruction - by academics, writers, journalists, artists, and social media users of a historical view of the contemporary Chinese and Western political systems and their underlying values and cultures. In this reconstruction, commentators conflate modern liberal democracy, capitalism, colonialism, and even racism. Liberal democracy and Western capitalism are seen as products of Europe's colonial expansion, while Chinese political ideas are portrayed as products of ancient, benign, and continuous civilisation (even if the term used for civilisation in modern Chinese, 文明, arrived in China in the late nineteenth century via a Japanese translation of a French philosophical text). 
Calling for the central government to take decisive action against the Hong Kong protests in 2019, for example, columnist and documentary film director Yu Zhongning 于中宁 (who made the documentary Openness and Co-operation: Operations Management in the Information Age in 1995) writes that at the heart of decolonialisation is the subversion of the theory of Western superiority and the creation of China's own 'narrative logic' 叙事 逻辑. ${ }^{16} \mathrm{Yu}$ asserts that some Chinese intellectuals lack a 'strategic vigilance' against the 'insidious, savagery, aggressive, predatory, and colonial nature of Western culture' deriving from the 'greedy and predatory nature of the white race'. Second, they wholly or partially accept that Western culture is superior. Third, while acknowledging that capitalism promotes professional ethics, the spirit of the rule of law and entrepreneurship, and although socialism itself is a great invention of Western culture, Yu contends that these valid elements are deviations from Western culture's fundamentally cruel colonial values. ${ }^{17}$

Journalist Zheng Ruolin 郑若麟, a fluent French speaker and author of The Chinese Are People Like You and Me (2014), as well as academics such as international relations specialist Zhang Weiwei 张维为, political scientist Jin Canrong 金灿㭉 and physicist and economist Chen Ping 陈平, are among the most vocal theorists of the reconstructed articulation of Chinese and Western cultures and institutions. Among them, Zhang is particularly prominent as the author of The China Wave: The Rise of a Civilizational State and host of the educational series China Now 《这就 是中国》, which has attracted hundreds of millions of viewers around the globe since Shanghai's Oriental TV began broadcasting it in January 2019. Through a combination of lectures, discussions, and questions and answers, Zhang analyses why the Chinese political model, based on a longstanding civilisation, is superior to what he portrays as decaying Westernstyle democracy based on a colonial history, looking at concepts such as democracy, rights, patriotism, universal values and freedom of speech. 
The People's Daily praises the series for guiding 'young viewers to think of the "theoretical strength" behind China's seventy years of development' under CCP rule. ${ }^{18}$

This reconstructed 'narrative logic' is reinforced by Chinese official and social media reports on China and the West to create a new national self-image and new perceptions of China's 'enemies'. Western countries' criticism of racism and colonial legacies is weaponised to fit into a narrative of an immoral West that is despised by its own people. China's stories, on the other hand, are reported as the source of envy and admiration of the West and the world. This is creating an increasing divide in information and knowledge both within and outside China. A recent online survey of the Chinese public's views of China's image and popularity around the world indicates that an overwhelmingly high percentage of the respondents (87 percent) chose answers that overestimated China's image in North America and Western Europe, whereas the latest fourteen-country Pew Research Center survey reported to the contrary — that is, a record-high majority of these surveyed countries had, on average, an unfavourable opinion of China. ${ }^{19}$

\section{Conclusion}

The CCP's construction of the superiority of the PRC's political system has evolved from a reactive, top-down propaganda approach to a partyendorsed proactive, grassroots re-theorisation, and re-writing of the histories of China and the West. In this re-theorisation, Western-style democracy and its values are portrayed as being based on a colonial heritage, which means they are morally inferior and bound to deteriorate; the China model, led by the CCP, by contrast, holds the moral high ground as the heir to and guardian of a great civilisation. The way in which the pandemic has left so many Western liberal democracies, and especially the US, in tatters has been a gift to the proponents of the theory of the superiority of the Chinese socialist system. 
This text is taken from China Story Yearbook: Crisis, edited by Jane Golley and Linda Jaivin with Sharon Strange, published 2021 by ANU Press, The Australian National University, Canberra, Australia.

doi.org/10.22459/CSY.2021.01 